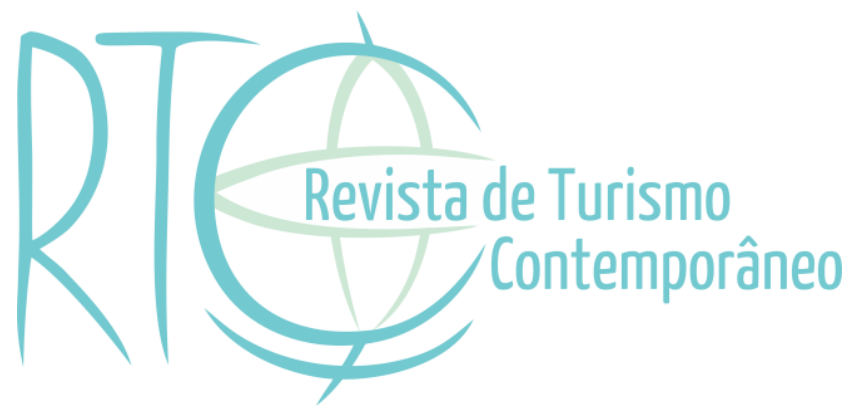

\title{
From cultural to creative tourism: urban and social perspectives from Oaxaca, México
}

\section{Do turismo cultural ao criativo: perspectivas sociais e urbanas de Oaxaca, México}

\author{
Daniel Barrera-Fernández \\ Professor e Pesquisador da Faculdade de Arquitetura da Universidade Autônoma Benito Juárez \\ de Oaxaca - UABJO, Oaxaca, México \\ E-mail: dbarrera.arqcu@uabjo.mx \\ Marco Hernández-Escampa \\ Professor e Pesquisador da Faculdade de Arquitetura da Universidade Autônoma Benito Juárez \\ de Oaxaca - UABJO, Oaxaca, México \\ E-mail: mescampa.arqcu@uabjo.mx
}

Artigo recebido em: 10-05-2017

Artigo aprovado em: 31-05-2017 


\section{ABSTRACT}

In recent years cultural tourists have started to be interested in activities mostly related to experiences, interacting with producers and being part of the daily life of residents, all of which has led to the development of creative tourism. Historically, the city of Oaxaca, Mexico, had a multicultural and creative background and these new visitors have seen how the local offer has increased rapidly following this trend. From an urban perspective, the objective of the research is to assess if creative activities have consolidated a creative neighborhood, and if this area differs from the consolidated area for cultural tourists. In order to achieve this goal, the distribution of traditional cultural tourism related activities and new creative attractions has been analyzed, showing two trends: on one hand there is an overconcentration on the previously consolidated tourist area, but on the other hand there is an extension of the area visited by tourists thanks to their increasing interest on searching the "authentic" and "alternative".

Keywords: Urban Tourism. Tourist-historic City. Heritage. Creative Class. Cultural Diversity.

\section{RESUMO}

Nos últimos anos os turistas culturais tornaram-se interessados em atividades relacionadas com experiências, interagindo com os produtores para ser parte das atividades cotidianas dos moradores, o que levou ao desenvolvimento do turismo criativo. Historicamente, a cidade de Oaxaca, no México, teve um ambiente multicultural e criativo, e desses novos visitantes vimos como a oferta local tem aumentado rapidamente seguindo esta tendência. A partir de uma perspectiva urbana, o objetivo da pesquisa é avaliar se as atividades criativas criaram um bairro criativo e se esta área é diferente da área turística cultural consolidada. Para isso, analisamos a distribuição das atividades relacionadas ao turismo cultural tradicional e novas atrações criativas, mostrando duas tendências: por um lado há uma densificação de atividades na área turística préconsolidado, mas por outro lado há uma extensão da área turística graças ao interesse crescente destes turistas na busca de autenticidade e do alternativo.

Palavras-chave: Turismo. Cidade Histórica e Turística. Patrimônio. Classe Criativa. Diversidade Cultural. 


\section{FROM CULTURAL TOURISM TO CREATIVE TOURISM}

In recent years there has been a trend in cultural tourism, in which aspects of the periphery of urban cultural tourism are becoming more and more important than aspects of the traditional nucleus. The periphery includes beliefs, cuisine, design, media, cultural diversity, architecture, nightlife, events and ways of life, among others. Therefore, social performances and intangible heritage increasingly play a role as tourist attractions by themselves.

The rise of these components relates to the loss of competitiveness of the offer based on monuments and arts, promoted by countless cities. On the contrary, intangible components bring uniqueness to the destination and they are more easily adapted to changes in the tourist market. In addition, the growth of these aspects is linked to the greater interest towards a tourism model based on experiences, as opposed to a tourism model in which the visitors are passive consumers of what has been arranged for them in advance.

Due to the mentioned trends, Richards and Wilson (2007) claim that cultural tourism is giving way to creative tourism. Creative tourism is based on the derived conception of sociology and anthropology that understands culture as codes of own behavior of a social group (Richards, 2005), values systems as a way of life (Landry, 2008) and a process, opposed to the idea of culture as a product, typical of the history of art and literature (De la Calle Vaquero \& García Hernández, 2010). In the idea of culture as a process the work of artists, actors, dancers and cooks plays the main role. In the idea of culture as a product the interest lies in museums, cultural facilities and monuments (Zukin, 1996). On the other hand culture is also understood as a mental content (Shore, 1996) and therefore experience becomes relevant as creator of such inner symbolic system for visitors.

The transition from cultural tourism to creative tourism is closely related to the development of so-called "creative cities". This idea is based on the fact that human creativity is the source of economic growth. This is another step in the post-Fordist economy, based on the creation of experiences rather than products. According to this idea, cities must develop, attract and retain people who can stimulate innovation, the so-called "creative class" (Florida, 2002). The creative class is mobile and will be attracted to environments with a wide cultural, tolerant, cosmopolitan, multicultural and dynamic offering (Law, 1996). Recent studies included in the list of most attractive cities for this social group examples such as Brooklyn, Philadelphia, 
Pittsburgh, Barcelona and Montreal, moving away from the traditional cultural capitals that attract millions of tourists (Richards, 2013).

Nowadays the concept of creative city has blurred and covers just about anything, becoming a component of all kinds of urban policies (Pratt, 2010). According to Comunian (2011), the theory of the creative class is too mechanistic and does not consider the relationship of these workers between them and their context, especially with the urban environment. According to Sasaki (2010), many cities have failed in their attempt to become creative in thinking that it is enough to attract those who make up the creative class as rated by Florida. They have not solved the problem of the inclusion of the rest of society and have not taken into account the impact on other aspects such as industry, employment, social welfare, education, health and the environment.

Creative cities seek to develop industries based on the production of meanings, the socalled "creative industries". This sector is led by non-economic factors such as social networks, local practices and symbolic meanings (Kim \& Short, 2008). According to Landry (2008), these industries include music, advertising, audiovisual and multimedia sector, visual arts, performing arts, crafts, design, industrial design, graphic arts and fashion. Other authors also include architecture and software sector (Department for Culture, Media and Sports, 2010). Creative industries tend to grow in turnover and employment generated in the long term but are more vulnerable to economic cycles than other sectors (Indergaard, 2013).

While tourism itself is not often included within the creative industries, tourism and tourists are intimately connected to the impact of income generation of these industries. In addition, constant innovation in these industries is exploited for renewing obsolete products and creating new ones in the current context of searching experiences (Richards, 2013). For its part, the World Tourism Organization and the European Commission (2005) consider that those cities that succeed in offering the right mix of people and creative industries, with an open, tolerant and diverse environment, not only attract the creative class as citizens and workers, but also travelers who share their same interests.

From an urban and social point of view, one of the negative aspects involved in creative tourism is its contribution to accelerate the gentrification process (Pratt, 2011). In a first phase artists settle in run-down neighborhoods, then the fashion business arrives and finally new residents move to the area (Cameron \& Coaffee, 2005). According to Zukin (1996), the presence 
of cultural activity confirms the symbolic hegemony of new residents, so the artists are often invited on new developments, due to their status as investors in the creative economy and its aesthetic contribution to renewed spaces, for example through public art.

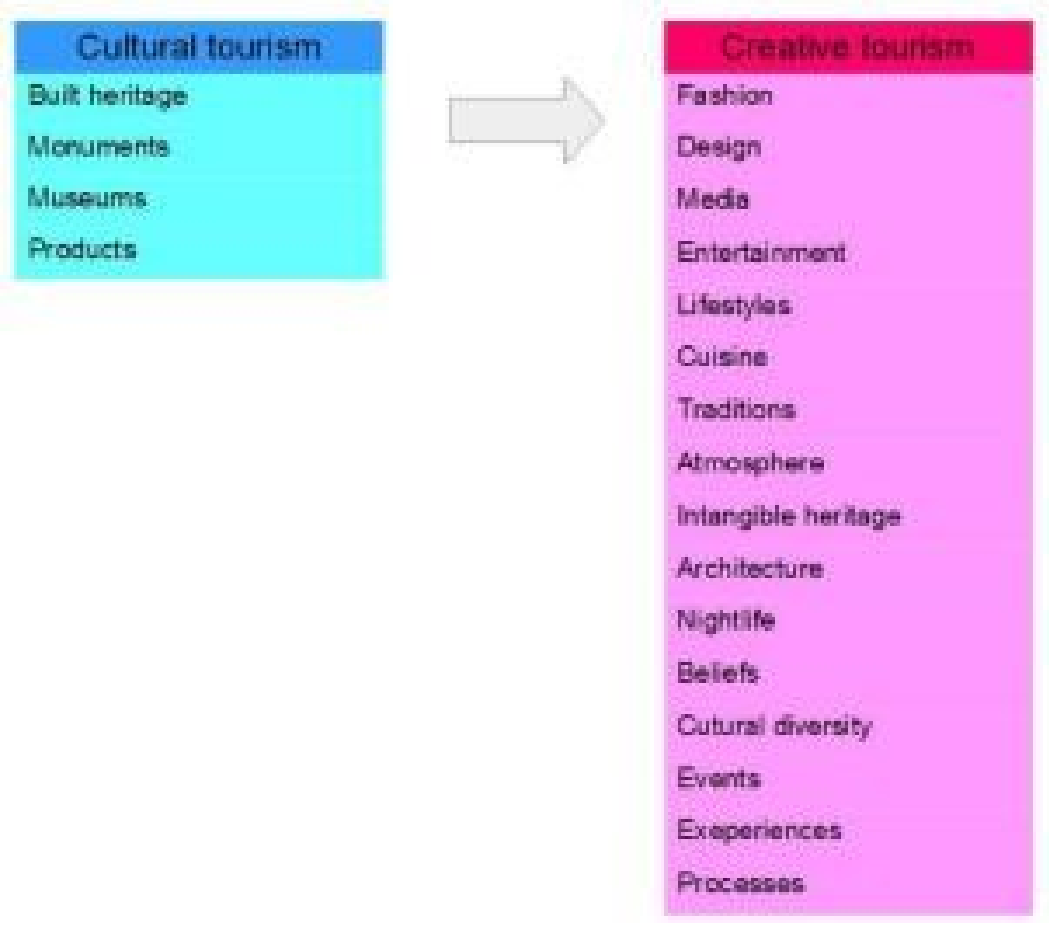

Figure 1. Components of cultural and creative tourism. Source: the authors.

\section{CONCENTRATION OF CREATIVE ACTIVITIES IN ORDER TO CONSOLIDATE NEW TOURIST NEIGHBOURHOODS}

To promote creative tourism, many cities have chosen to encourage the creation of areas where innovative activities are concentrated and creators mingle with visitors in a cosmopolitan atmosphere, it is what Landry (2008) calls the "creative environment". The author considers four categories of elements that cannot be missing in these spaces: material aspects, activities, attitudes and management related aspects. Material aspects include location of the neighborhood, history, heritage and infrastructures. Activities include cleaning service, waste management, social services, traditions, level of training and range of activities taking place. In terms of attitudes, openness, tolerance, entrepreneurship, external image of the city and the existence of a culture of curiosity, creativity and competitiveness are considered important. Finally, the 
organization must be based on the strengthening of individuals and companies, public-private collaboration and move from words to deeds.

According to Chapple, Jackson and Martin (2010), the first neighborhoods of this type begin to develop in the 70s in the USA, with examples such as SoHo in New York and the commercial and craftsmen district in Los Angeles, although the antecedents are to be found in examples like Montmartre In Paris and Greenwich Village in New York, both from the beginning

of the $20^{\text {th }}$ century. Currently there are examples of creative neighborhoods throughout the world, including Amsterdam, Singapore, Hong Kong, London, Chicago, Berlin, Shanghai, San Francisco and Beijing (Zukin \& Braslow, 2011).

Van der Borg and Russo (2005) claim that to be successful a creative neighborhood needs a strong support of the administration in organizing events, financial support to entrepreneurs, heritage conservation and promotion. Meanwhile, Cohendet, Grandadam and Simon (2011) consider that a creative neighborhood must have a fluid communication between the underground, middleground and upperground layers of the city. The first layer includes the artists who live and work outside the mainstream market. The second layer includes organisations that allow the transmission of knowledge to generate creativity, the third layer includes formal institutions and companies that transform creativity into products. When the middleground layer does not exist or has been neglected, it hinders the emergence of creativity. In these spaces, accessibility by public or private transport is as important as walking. Since the creative economy is based on ideas and imagination, the arts occupy a preferred place as an aesthetic manifestation and as part of other activities, among which are design, fashion, small commerce in general and leisure.

Material and immaterial heritage also acquires a new role as a source of inspiration and because it anchors the new activities in history and in the local culture. Culture is seen as the sum of the past and present creativity, therefore it offers numerous resources to keep innovating. This has been recognized by the Declaration of Hangzhou (UNESCO, 2013), which considers that urban regeneration based on heritage and sustainable tourism are a powerful economic subsector to create green jobs, stimulate local development and enhance creativity.

Creative neighborhoods seek to offer a cosmopolitan atmosphere that is summarized in several components. In them a wide cultural offer, iconic architecture and different lifestyles are concentrated to offer an exciting image. In addition, it is important to show scenes of people 
meeting and chatting, it is especially valued if it occurs in a multiethnic (Richards \& Palmer, 2010) and tolerant environment towards diversity of sexual orientations (Bell \& Jayne,

2004). These areas combine official or commercial art with other more popular and transgressive forms. They are also characterized by their nightlife atmosphere with trendy restaurants and bars. In these areas a careful design of public spaces is delivered, such as squares and pedestrian streets and benches, fountains, ornamental vegetation and urban art are installed, people practicing sports or doing outdoor activities collectively is especially valued (Richards \& Wilson, 2007).

In a creative neighborhood, the distinction between cultural activities that are not for profit and creative industries that seek the economic benefit is blurred. Both realities are complementary and rooted in the territory, history and local knowledge (Santagata, Russo, \& Segre, 2007), which increases the sense of belonging to a place as opposed to homogeneous spaces of mass tourism.

In these environments tourists come into contact with new ideas, people, products, attitudes, languages and visual manifestations. In particular, visitors are attracted by the expressions of local culture and creativity such as built heritage, performing arts and gastronomy. The essence of the neighborhood is therefore creative production and consumption, rather than the mere presence of cultural attractions that support cultural tourism in its traditional and passive way (Richards \& Wilson, 2007).

The concentration of activities in creative neighborhoods makes it possible to share services, exchange experiences and develop economies of scale. In addition, specialization allows the use of the tools of urban planning incorporating the specific needs of this sector. Casual encounter and interaction between people with different talents, backgrounds, age, economic capacity, schedules and lifestyles promotes artistic experimentation (Scott, 2000) and the emergence of a "cafe culture" where leisure, culture and socialization are mixed (Van der Borg \& Russo, 2005). The presence of these spaces of consumption is vital because it represents the economic and cultural success of users and the neighborhood (Bell \& Jayne, 2004).

Chapple, Jackson and Martin (2010) distinguish two types of creative neighborhoods: those which are formally planned and those that are informally created by artists themselves. The first case usually begins by installing an iconic cultural facility, thus requiring a significant investment of public money, in this type of projects the benefits usually do not reach the 
artists. In the second type the problem is the lack of long-term stability, due among other factors to the lack of functional integration and formal organization (Hitters \& Richards, 2002).

In both cases the same process is repeated. At first artists arrive, they attract consumers, who are looking for something different, bohemian and authentic. In a second step creative entrepreneurs arrive, who attract new consumers and finally real estate developers. As a result the artists end up moving to another part of the city (Zukin \& Braslow, 2011).

\section{CASE STUDY, OBJECTIVES AND METHODOLOGY}

The city of Oaxaca (officially called Oaxaca de Juárez) is the capital of the homonymous state, located in South Mexico. The city lies in the region of the Central Valleys, which concentrates most of the state's urban population. The city of Oaxaca has got 264,251 inhabitants and its metropolitan area accounts for 593,522 residents (Instituto Nacional de Estadística y Geografía, 2016). The city was founded by the Aztecs in 1486 with the name of Huāxyacac, in 1532 it was officially considered a city by the King Charles V and called Antequera, name kept until Mexican independence in 1821, when it was renamed as Oaxaca.
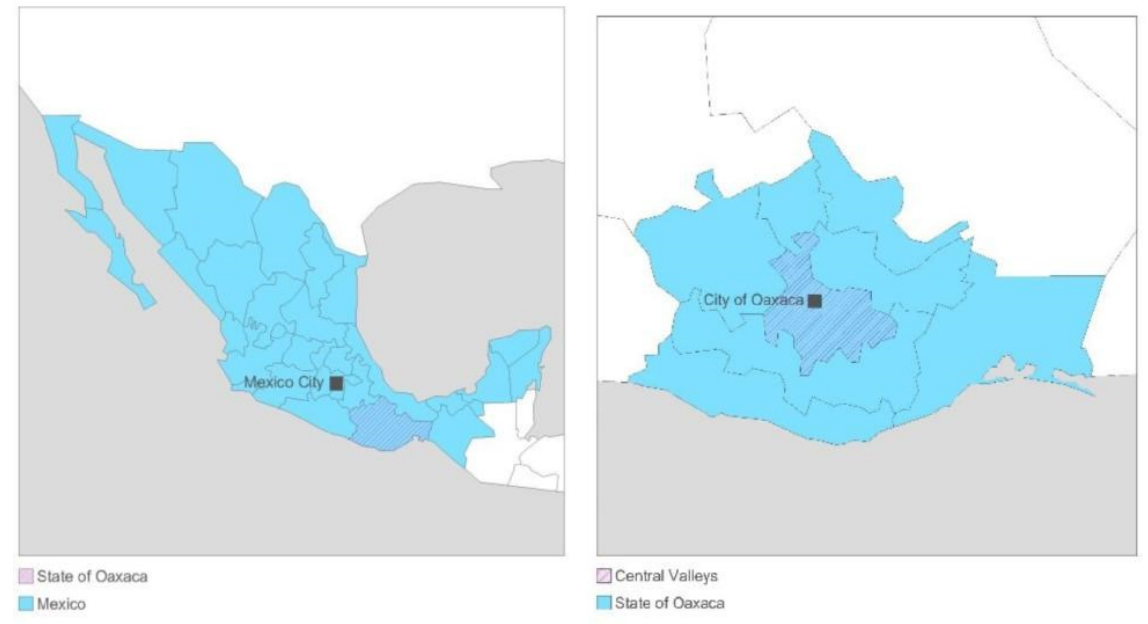

$\square$ Central Valleys G

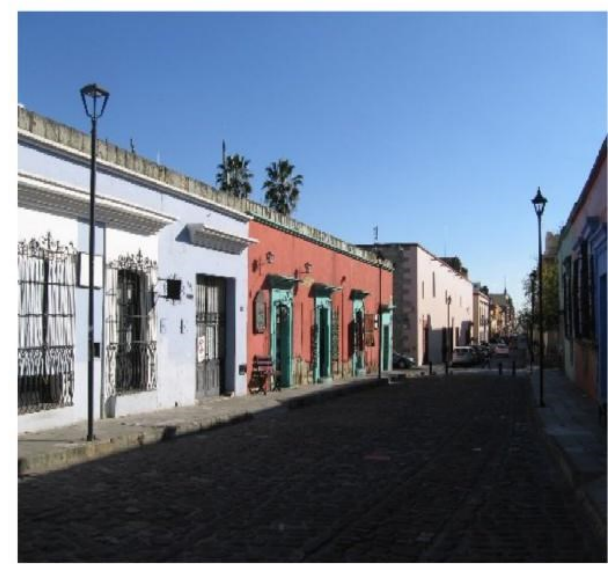

Figures 2 and 3. Location of the state of Oaxaca and the city. Source: the authors.

Tourism represents a major source of income and employment in the city. In 2012 this sector created 9,557 direct jobs and 23,893 indirect jobs (Secretaría de Turismo, 2014). The city was visited in 2014 by 952,587 tourists (853,882 from Mexico and 98,705 from abroad) (Instituto Nacional de Estadística y Geografía, 2015). Culture and heritage are the most important attractions in the city due to the concentration of monuments and colonial buildings in its city 
centre and the close location of the archaeological site of Monte Albán, which were included in UNESCO's World Heritage List in 1987. Apart from heritage, the city centre offers a wide range of museums covering from historical facts to archaeology and contemporary art. Intangible heritage is also a major visitor attraction, especially represented by arts and crafts, cuisine and traditions rooted in the ethnic diversity of the area. Among traditional festivities, the Guelaguetza is the most popular among national ad foreign visitors, which is celebrated every summer.
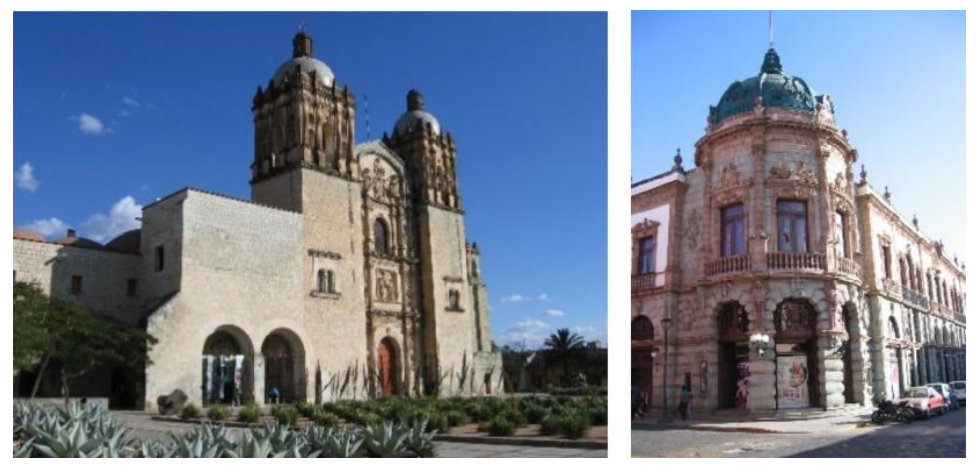

Figures 4, 5 and 6. Santo Domingo Church, Macedonio Alcalá Theatre and typical street in the city centre. Source: the authors.

The city of Oaxaca attracts independent visitors interested in its creative designs, both traditional and avant-garde. Oaxaca hosts a vast a diverse indigenous culture, represented by a concentration of native languages and cultural groups. The state of Oaxaca has got the most linguistic diversity in Mexico, 34\% people speak an indigenous language while in whole Mexico only $14 \%$ do (Instituto Nacional de Estadística y Geografía, 2016). This cultural diversity results in a rich offer of arts and crafts. In recent years some groups have established their own warehouses or shops to sell their own production directly without intermediaries, which is particularly attractive for visitors searching the authentic and ethic. In addition, the city maintains a continuous social tension which also enriches artistic creation linked to political movements, especially in the form of graffiti and pamphlets, this being another attraction for creators from all over the world that settle in the city for short or long terms. As a result, the mix of indigenous cultures, social movements and foreign artists results in a very prolific creative sector, acknowledged by independent travelers. It is important to mention that cultural richness of Oaxaca has developed through the centuries and its dynamics occur independently from tourist activity. However, all of the social performances have become raw material for the tourist sector and some have been highlighted or reinterpreted. 

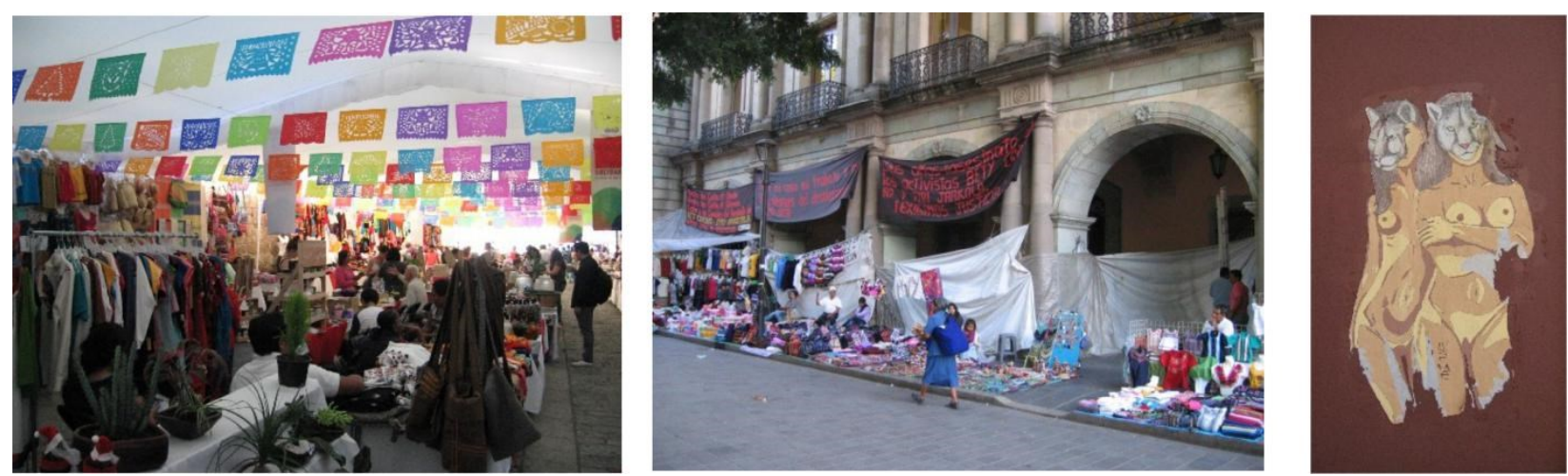

Figures 7,8 and 9. Temporary arts and crafts market, occupation camp at the State's

Government Palace and innovative lesbian feminist wall painting in the public space. Source: the authors.

In addition, the city centre hosts a number of upmarket art galleries and studios of many kinds, where individual creators or groups of them live, work and show their innovations. Graphic design is particularly innovative and has consolidated as a specialized creative activity. The increase of creative tourism in the city has encouraged the opening of new facilities related to the former in the most visited central streets.

Furthermore, the interest of travelers in local gastronomy has motivated the refurbishment or renovation of traditional outlets, shops and markets, adding appeal to the city's tourist offer. In particular, local products such as mezcal, chocolate, mole and coffee are widely acknowledged and new premises have been opened that not only sell these specialties but offer new experiences. For example it is possible to choose ingredients and observe how chocolate is produced in small factories in the city centre and organic and fair trade coffee producers sell their beans in special shops.
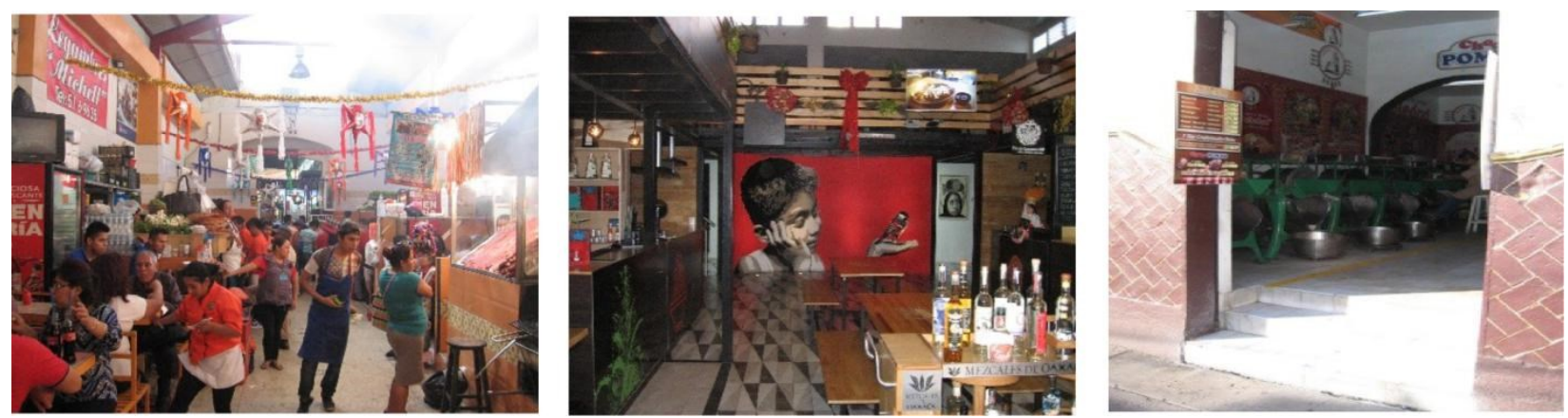

Figures 10, 11 and 12. Traditional food market, new food market and traditional chocolate workshop and store.

Source: the authors. 
The objective of the present research is to assess if creative activities have consolidated a creative neighborhood in the city of Oaxaca, and if this area differs from the consolidated area for cultural tourists. In order to achieve this goal, the following steps have been developed:

1. Tourism related activities have been classified taken into account their belonging to the cultural or creative segments, following the division previously explained. Considering its application to the reality Oaxaca, the following activities have been identified:

- Cultural tourism:

. Area included in UNESCO's World Heritage List

. Most visited museums.

. Most visited monuments.

- Creative tourism:

. Avant-garde activities:

+ Art galleries and studios.

+ Graphic design workshops and stores.

+ Contemporary design stores and studios.

. Renovated traditional activities.

+ Arts and crafts workshops, stores and markets.

+ Traditional cuisine markets and facilities.

+ Refurbished mezcalerías.

+ Local chocolate and coffee shops.

2. In order to identify which of the former activities are clearly orientated to tourists, three sources have been considered. Firstly, the tourism policy related agencies (Secretaría de Turismo, 2014; Secertaría de Turismo y Desarrollo Económico, 2016; Visit Mexico, 2016) identify what are some of the most visited attractions in the city. Secondly, field work has been developed to observe directly what facilities are visited by tourists.

Thirdly, interviews have been conducted to shop assistants and museum's staff to confirm if tourists are a relevant part of their customers or attendants.

3. Maps have been developed to show the location of cultural tourism and creative tourism related activities separately, together with synthesis maps. 


\section{DISCUSSION}

According to the previously referred sources and field work, the most visited cultural tourism related attractions are a few number of museums and monuments. The most visited ones are Santo Domingo Church and Museum, La Soledad Church, the Zócalo (main square) surrounded by the State's Government Palace and the Cathedral, Santo Domingo Cultural Centre, Macedonio Alcalá Theatre and Benito Juárez Museum. These facilities serve as nodes and in the streets connecting them there are other highly visited facilities such as the Museum of Contemporary Art and Rufino Tamayo Museum, together with a number of Baroque churches. It is possible to see that the most visited area in terms of traditional cultural tourism covers a limited area of the much wider sector included in UNESCO's World Heritage List, meaning that a large section of the historic centre remains mostly unvisited although possessing relevant heritage values.

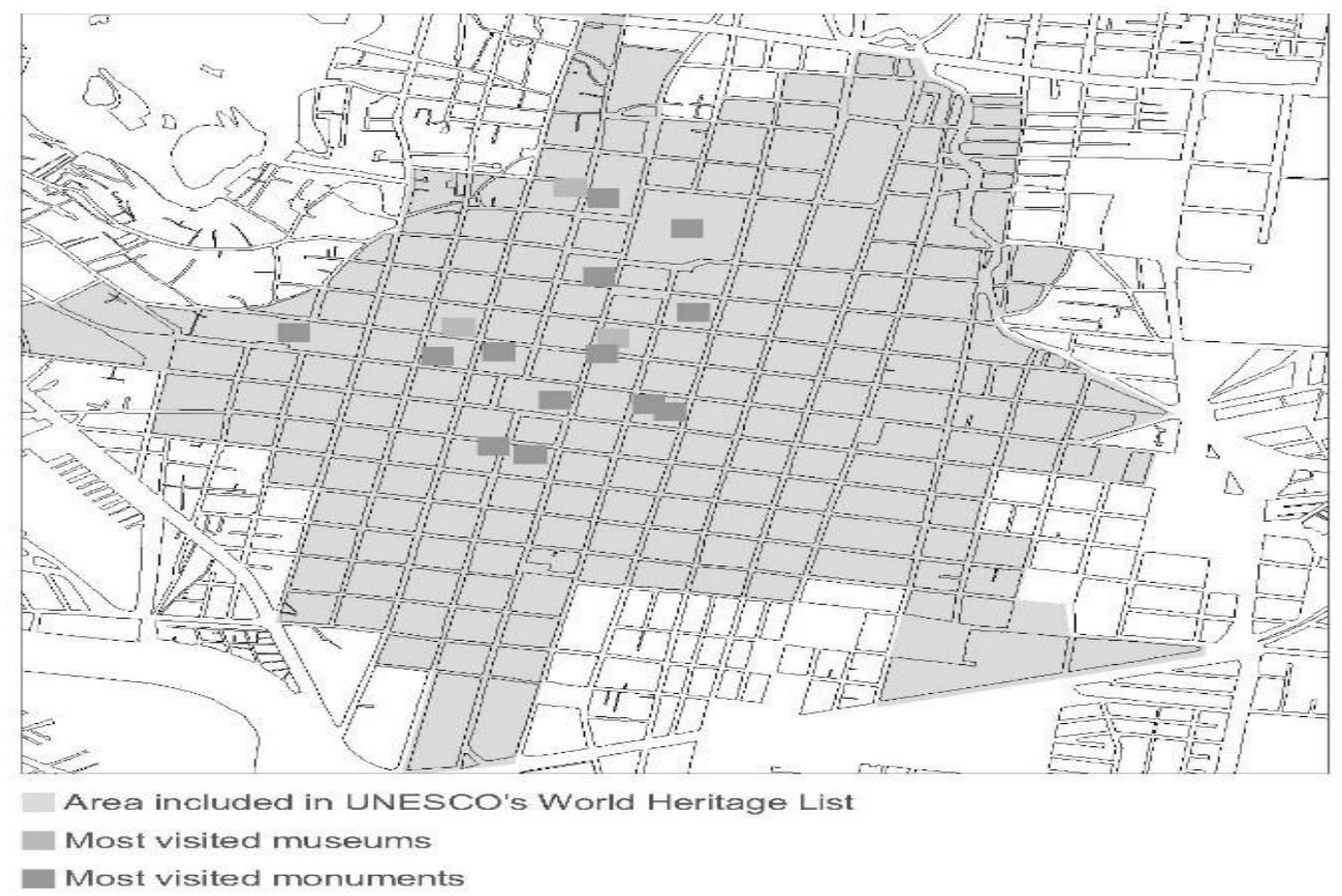

Figure 13. Location of the most visited cultural tourism related attractions. Source: the authors.

Focusing on creative tourism related activities, they have been divided into two groups. The first one relates to avant-garde design and arts. As shown in the map, these activities are mostly concentrated in a small section of Macedonio Alcalá Street and surrounding streets 
located between Santo Domingo Church and Museum and the Zócalo, which are the virtual limits of the area where most tourists spend their time in the city. Most of these businesses have opened in the last few years and their location shows their high dependence on tourists.

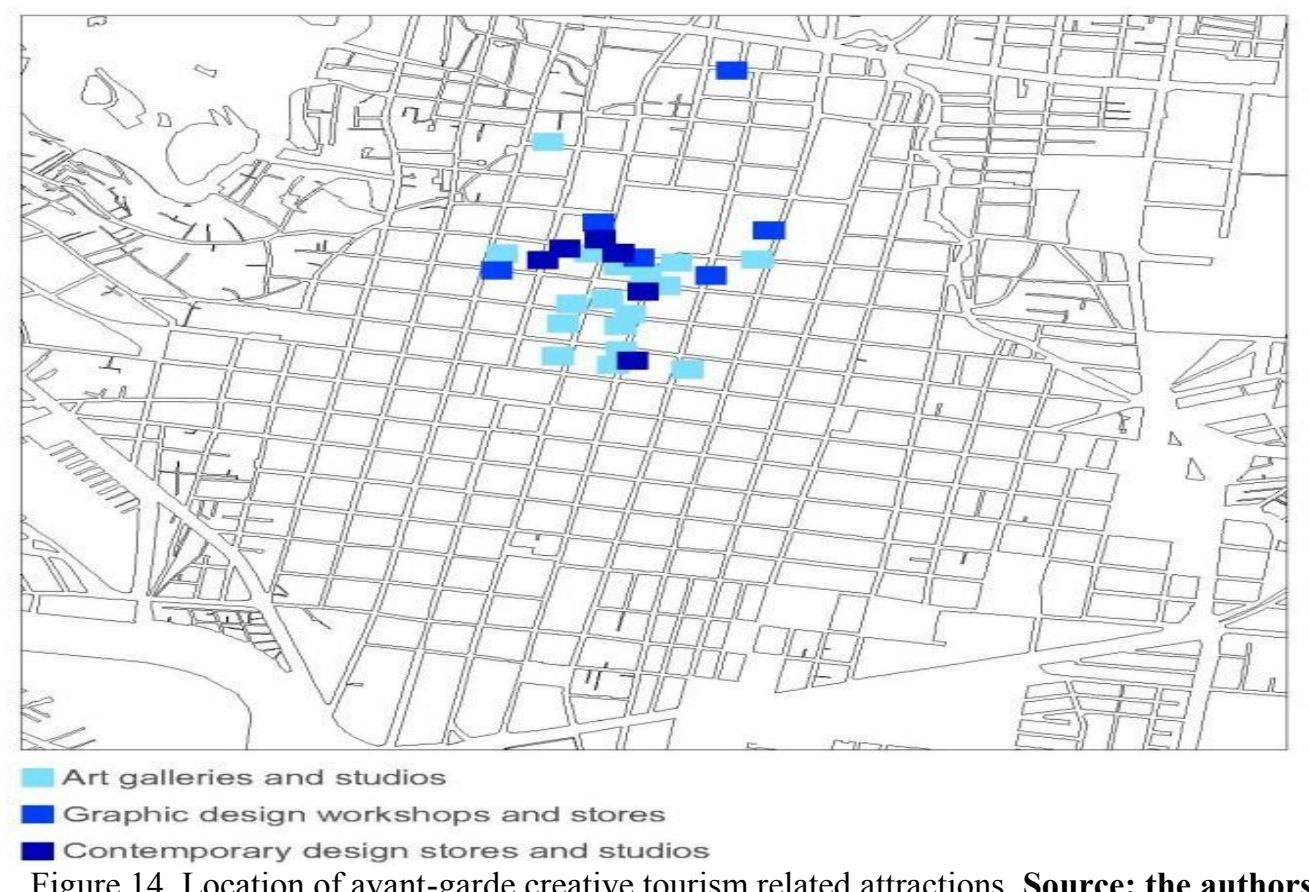

The second group of creative tourism related activities included those traditional businesses that have been renovated due partly to their demand by travelers. As it was mentioned above, many creative tourists are interested in having experiences rather than just being observers, and they try to mix with local people in their daily life. In Oaxaca, arts and crafts, traditional cuisine and local products such as mezcal, coffee, chocolate and mole fulfill their expectations. As opposite to the previous map, it can be observed that the extension of these activities is much wider, in fact there have been two trends. On one hand, traditional stores, markets, restaurants and workshops have adapted themselves to their new customers. They have not moved to more central locations, it is the tourists who have "discovered" these facilities. On the other hand, new facilities clearly tourist-oriented have opened in the same area than avantgarde activities, namely in the tourist core between Santo Domingo and the Zócalo. 


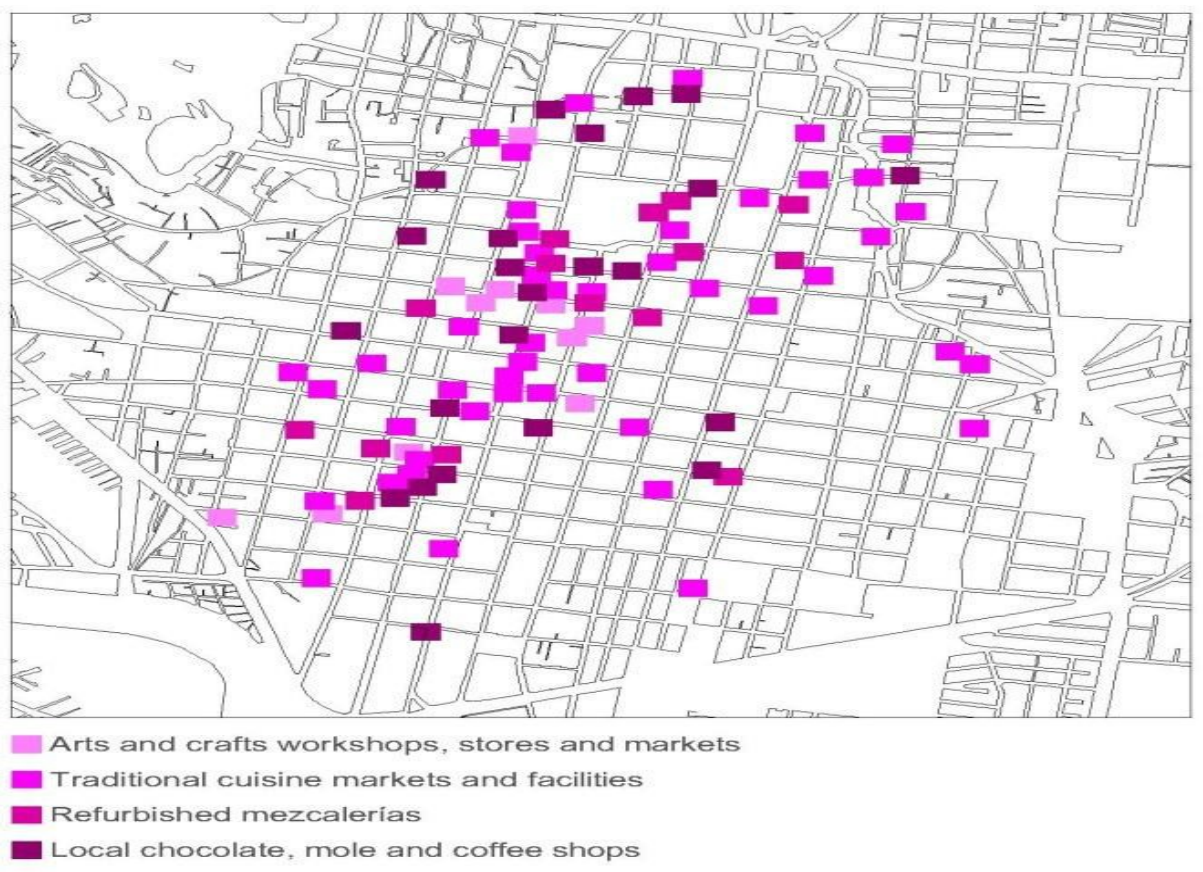

Figure 15. Location of creative tourism related attractions adapted from traditional local activities. Source: the authors.

The data shown suggest that the traditional heritage assets relate directly with gentrification associated to very specific urban areas. On the other hand, creative tourism related activities spread into a wider area in the city, which has relevant consequences. Firstly, it leads to a more profound knowledge and experience during the visit. Secondly, it helps to disseminate the economic benefits brought by tourists among a larger number of businesses. Thirdly, the “discovery" by creative tourists of neighbourhoods previously considered as lacking interest has drawn the attention of policy makers, and as a result these areas have started to be subject of regeneration and improvement. In addition, creative tourism potentially has the virtue of not producing massive gentrification and therefore it relates to social and economic sustainability. Finally, although not studied in this work, it can be stated that Oaxaca also has a complex social life which in some cases leads to substantial manifestations and it has attracted a number of activists and political actors. This is another yet unexplored potential of the city. In general, alternative tourism seems to be a major complement for traditional attractions and specifically in the case of study.

\section{CONCLUSION}


If we overlap the area where the three different kinds of activities concentrate, it can be concluded that traditional cultural attractions are located in a reduced area of the historic centre, something in line with the spatial concentration needed for cultural tourism, since, according to Jansen-Verbeke and Lievois (2001), density of activities facilitates the location of tourist services such as hotels and restaurants and makes them profitable. In addition, tourists need certain physical concentration to walk between attractions and to visit them in the short time that they spend in urban destinations.

Creative tourism related activities have increased intensity of use in a more reduced area of the already consolidated cultural tourism sector. Particularly responsible of this trend are upmarket and avant-garde design and art galleries and workshops. On the contrary, traditional products and arts and crafts have increased their interest among tourists, which has encouraged the renovation of stores and the opening of new ones in the consolidated area. Tourists walking off the beaten track (Maitland, 2010) has made these businesses more profitable and some of them have managed to keep both kinds of clients, residents and tourists. However, this is a very weak balance and in some occasions the increasing tourist visit has forced many local customers to move to other premises, this is the case of the Traditional Market and the Gastronomic Market, where prices and offer tends to be increasingly orientated towards visitors. In fact this is the contradiction of creative tourists: they are interested in the authentic and in mixing with locals, but when this happens prices raise and products and establishments are transformed to fit their expectations and comfort, becoming somehow artificial. As a result, independent travelers seek another hidden treasures and the process starts again.

Creative tourism, and alternative tourism in particular, relate to potential benefits for the cities because of having the potential of involving larger areas not necessarily linked to traditional assets like monuments. Gentrification might be mitigated with this kind of tourist offer and therefore, sustainability can be reinforced. 


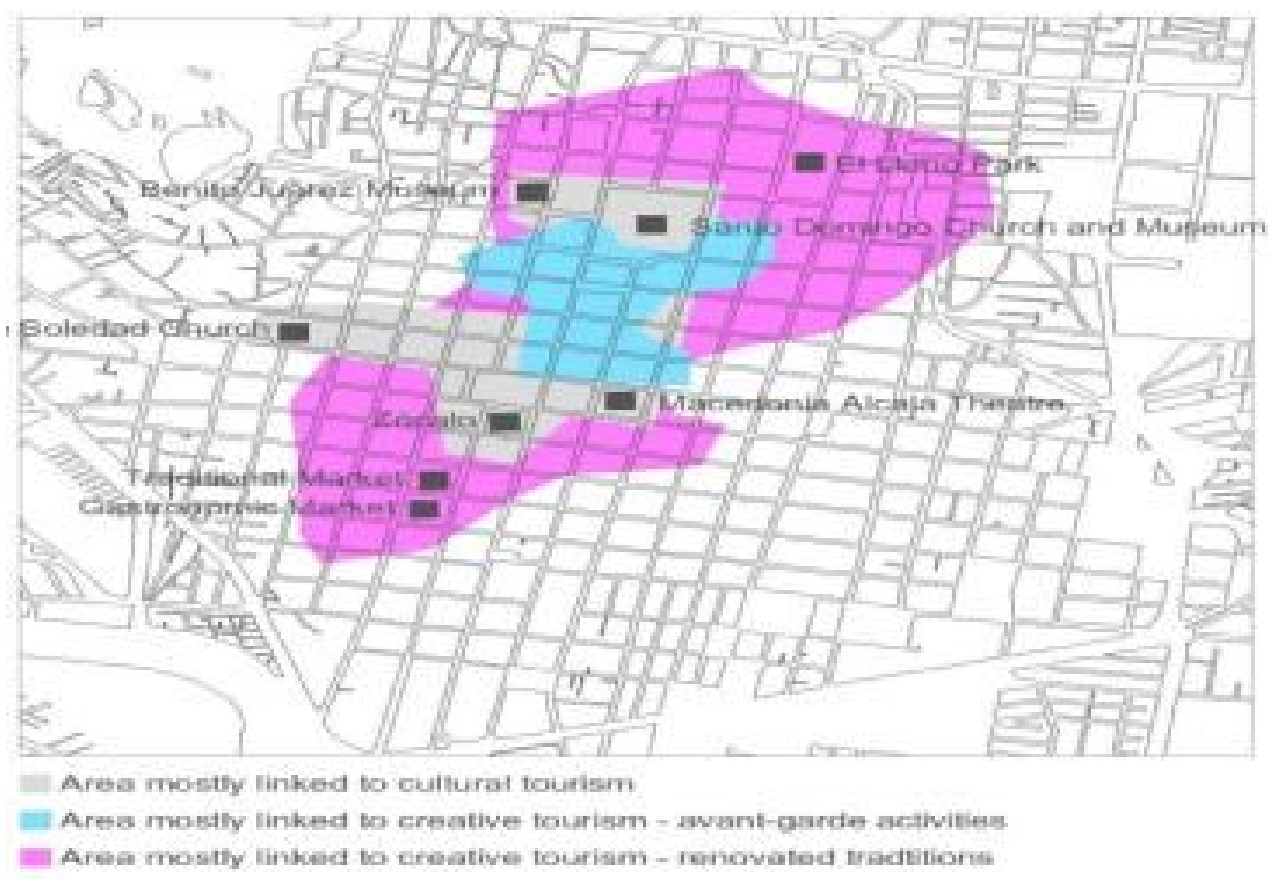

Figure 16. Location of creative tourism and cultural tourism areas. Source: the authors.

\section{REFERENCES}

Bell, D. \& Jayne, M. (2004). City of quarters. Urban villages in the contemporary city. Aldershot: Ashgate.

Cameron, S. \& Coaffee, J. (2005). Art, gentrification and regeneration: from artist as pioneer to public arts. European Journal of Housing Policy, 5(1), 39-58.

Chapple, K., Jackson, S., \& Martin, A. J. (2010). Concentrating creativity: the planning of formal and informal arts districts. City, Culture and Society, 1, 225-234.

Cohendet, P., Grandadam, D., \& Simon, L. (2011). Rethinking urban creativity: Lessons from Barcelona and Montreal. City, Culture and Society, 2, 151-158.

Comunian, R. (2011). Rethinking the creative city: The role of complexity, networks and interactions in the urban creative economy. Urban Studies, 48(6), 1157-1179.

De la Calle Vaquero, M. \& García Hernández, M. (2010). Reflexiones sobre el turismo cultural. La aportación de la cultura en la conformación de flujos turísticos emisores en España y la Comunidad de Madrid. Anales de Geografia, 30(2), 31-58.

Department for Culture, Media and Sports. (2010). Creative industries economic estimates. Experimental statistics. Headline findings.

Florida, R. (2002). The rise of the creative class: And how it's transforming work, leisure, community and everyday life. New York: Basic Books. 
Hitters, E. \& Richards, G. (2002). The creation and management of cultural clusters. Creativity and Innovation Management, 11(4), 234-247.

Indergaard, M. (2013). Beyond the bubbles: Creative New York in boom, bust and the long run. Cities, 33, 43-50.

Instituto Nacional de Estadística y Geografía. (2015). Anuario estadístico y geográfico de Oaxaca. Mexico: Instituto Nacional de Estadística y Geografía.

Instituto Nacional de Estadística y Geografía. (2016). Información por entidad. Retrieved from http://cuentame.inegi.org.mx/monografias/informacion/oax/poblacion/.

Jansen-Verbeke, M. \& Lievois, E. (2001). Analysing heritage resources for urban tourism in European cities. In D.G. Pearce \& R.W. Butler, Contemporary issues in tourism development. London and New York: Routledge.

Kim, Y.\& Short, J.R. (2008). Cities and economies. Oxon and New York: Routledge.

Landry, C. (2008). The creative city. A toolkit for urban innovators. London and New York: Routledge.

Law, C.M. (1996). Urban tourism. Attracting visitors to large cities. London and New York: Mansell Publishing Limited.

Maitland, R. (2010). Everyday life as a creative experience in cities. International Journal of Culture, Tourism and Hospitality Research, 4(3), 176-185.

Pratt, A.C. (2010). Creative cities: Tensions within and between social, cultural and economic development. A critical reading of the UK experience. City, Culture and Society, 1(1), 13-20.

Pratt, A.C. (2011). The cultural contradictions of the creative city. City, Culture and Society, 2, 123-130.

Richards, G. (Ed.). (2005). Cultural tourism in Europe. Association for Tourism and Leisure Education.

Richards, G. (2013). Creativity and tourism in the city. Current Issues in Tourism, 19(2), 119144.

Richards, G. \& Palmer, R. (2010). Eventful cities. Cultural management and urban revitalization. Elsevier.

Richards, G. \& Wilson, J. (2007). Tourism development trajectories: From culture to creativity? In G. Richards \& J. Wilson (Eds.), Tourism, creativity and development. London: Routledge.

Santagata, W., Russo, A.P., \& Segre, G. (2007). Tourism quality labels: An incentive for the sustainable development of creative clusters as tourist attractions? In G. Richards \& J. Wilson (Eds.), Tourism, creativity and development. London: Routledge. 
Sasaki, M. (2010). Urban regeneration through cultural creativity and social inclusion: Rethinking creative city theory through a Japanese case study. Cities, 27, 53-59.

Scott, A. (2000). The cultural economy of cities. SAGE Publications.

Secretaría de Turismo. (2014). Agendas de competitividad de los destinos turísticos de México. Oaxaca. Oaxaca: Instituto Politécnico Nacional.

Secretaría de Turismo y Desarrollo Económico. (2016). Ciudad de Oaxaca. Retrieved from http://oaxaca.travel/.

Shore, B. (1996). Culture in mind: Cognition, culture, and the problem of meaning. Oxford University Press.

UNESCO (2013). The Hangzhou Declaration. Placing culture at the heart of sustainable development policies. Hangzhou, $17^{\text {th }}$ May 2013.

Van der Borg, J. \& Russo, A.P. (2005). The impacts of culture on the economic development of cities. Rotterdam: Erasmus University.

Visit Mexico. (2016). Oaxaca. Retrieved from http://www.visitmexico.com/es/oaxaca.

World Tourism Organization \& European Commission. (2005). El turismo urbano y la cultura. La experiencia europea. Madrid: World Tourism Organization.

Zukin, S. (1996). The cultures of cities. Oxford: Blackwell Publishing.

Zukin, S. \& Braslow, L. (2011). The life cycle of New York's creative districts: Reflections on the unanticipated consequences of unplanned cultural zones. City, Culture and Society, 2, 131140 . 